\title{
Determinants of smallholder farmers' decision to adopt adaptation options to climate change and variability in the Muger Sub basin of the Upper Blue Nile basin of Ethiopia
}

\author{
Abayineh Amare* and Belay Simane
}

\begin{abstract}
Smallholder farmers' decisions to adopt adaptation options in response to climate change and variability are influenced by socioeconomic, institutional, and environmental factors, indicating that decision patterns can be very specific to a given locality. The prime objective of this research is to identify factors affecting smallholder farmers' decisions to adopt adaptation options to climate change and variability in the Muger River sub-basin of the Blue Nile basin of Ethiopia. Both quantitative and qualitative data were collected using a semi-structured questionnaire, focused group discussions, and key informant interviews from 442 sampled households. Frequency, mean, Chi-square test, and one-way ANOVA were used for analysis. Furthermore, a multinomial logit model was employed to analyze the data. Results signified that small-scale irrigation, agronomic practices, livelihood diversification, and soil and water conservation measures are the dominant adaptation options that smallholder farmers used to limit the negative impact of climate change and variability in the study area. The results further revealed that adoption of small-scale irrigation as an adaptation to climate change and variability is significantly and positively influenced by access to credit, social capital, and the educational status of household heads. Greater distance to marketplace and size of farmland negatively affected the use of agronomic practices, whereas crop failure experience and access to early warning systems have a positive influence. The results also point out that adoption of soil and water conservation measures are positively affected by exposure to early warning systems, greater distance to the marketplace, and larger size of cultivated land. It is also noted that livelihood diversification is negatively influenced by socioeconomic factors such as education, the gender of the household head, and livestock ownership. Overall, the results suggested that improved policies aimed at increasing the adoption of adaptation options to offset the impact of climate change and variability should focus on: creating effective microfinance institutions and effective early warning systems, increasing farmer awareness, improving infrastructure, and encouraging farmers' membership to many social groups. The results further suggested that agroecological and gender-based research should be promoted and increased for a more holistic understanding of farmer adaptation options.
\end{abstract}

Keywords: Adoption, Adaptation options, Determinant, Climate change

\section{Background}

Climate change is expected to have significant adverse effects on agricultural production in Africa, in particular, due to the continent's dependence on rain-fed agriculture

${ }^{*}$ Correspondence: abayineh.amare@aau.edu.et

Centre for Environment and Development, College of Development

Studies, Addis Ababa University, p.o.box 1176, Addis Ababa, Ethiopia
[1-4]. Empirical studies show that climate change and variability already place a heavy burden on smallholder farmers, and their livelihoods will be further threatened by ongoing climate change [5-7].

Like most African countries, Ethiopia is frequently identified as a country that is highly vulnerable to climate variability and change [8-10]. The agriculture sector has been playing a very significant role in providing 
food, employment, and income to the majority of people in Ethiopia. It accounts for about $42.9 \%$ of gross domestic product (GDP), $80 \%$ of employment, and $88 \%$ of export earnings [11]. However, climate change remains the major challenge to the development of agriculture and food security [12]. Despite its high contribution to the overall economy, the sector is inherently sensitive to climate climate-related disasters like drought and flood and is among the most vulnerable sectors to the risks and impacts of global climate change [13]. Studies indicate that Ethiopian agriculture is characterized by a low use of external inputs and it is highly vulnerable to climate variability and change [10, 14-17]. The impact on agriculture is manifested by increasing incidence of floods, droughts, and unpredictable rainfall $[18,19]$ and has resulted in food shortage and famine in the past [20-23], and they continue to pose a serious threat to Ethiopia's development [12].

Because of the huge contribution of agriculture to Ethiopian's economy and its high susceptibility to climate change and climate-related extreme events-droughts and floods, it is important to study adaptation strategies to overcome the anticipated adverse impacts. It has been recognized that adaptation to climate change and variability is one of the policy agenda widely supported to help smallholder farmers to limit the negative effects of climate change in this sector [24-26]. It has been noted that the existing support system determines differences in adaptation options to climate hazards among households to households and region to region. There is considerable evidence that climate change holds back the progress of Ethiopian agriculture [27-29]. However, results from these studies were inclusively focused on the impact of climate change on agricultural production and productivity and suggested adaptation strategies, but failed to address the driving forces that determine household's choices of adaptation options. This presents an important limitation since farmers' responses to climate change or their choice of adaptation strategies have been dictated by a host of environmental and socioeconomic factors.

Furthermore, studies have been undertaken to analyze the impact of climate change and factors affecting the choice of adaptation methods in mono-crop and mixed crop production system in Africa at the regional level [25, 30, 31]. The aggregate nature of these studies, however, makes it very difficult to provide insights in identifying country-specific impacts and adaptation methods given the heterogeneity of countries included. Diversity in agroecological features, socioeconomic, institutional, and environmental issues was not addressed in these studies. This has limited the contribution of adaptation strategies, as the adoption of adaptation strategies to climate variability and change is context specific.
So far, there is only a study specific to the Nile River Basin that investigates factors affecting the choice of adaptation methods [32]. Although the study by Deressa et al. [32] provides important information, it is limited to an analysis of crop production systems and does not take into account the dramatic spatial heterogeneity (i.e., in soil qualities, steepness of slopes, and access to infrastructure), socioeconomic, and environmental diversity. Thus, there is limited scientific evidence on which to base feasible development policy interventions, although these are urgently necessary to strengthen effective adaptation measures that can be implemented by smallholder farmers and help them to reduce food insecurity. Thus, an understanding of the determinants of a household decision to adopt a particular adaptation strategy among the available choices is crucial to provide insights and identify target variables that enhance the use of adaptation strategies. In this context, the results of the study can potentially provide an informed basis on which policy recommendations can be drawn from these insights to facilitate the adoption of adaptation strategies at the local level so that the adverse impact of climate change and variability on their livelihoods can be limited.

Hence, the objectives of this study are to explore adaptation strategies used by smallholder farmers in response to the adverse effects of climate change and variability and to analyze factors that influence smallholder farmers' decisions to adopt adaptation strategies in the Muger River sub-basin of the Blue Nile River Basin.

\section{Description of the study area Biophysical setting}

Muger sub-basin is part of the upper Blue Nile basin and covers a total area of $8188 \mathrm{~km}^{2}$. Muger River flows from the southeast of the basin into upper Blue Nile basin. The altitude in Muger sub-basin ranges between 953 and 3550 masl. The highlands in the eastern and southern part of the sub-basin are higher in altitude, greater than $2600 \mathrm{~m}$ up to $3550 \mathrm{~m}$. The lowlands along the Muger River have lower altitude less than 1700 masl [33].

The sub-basin has an annual rainfall that varies between 833 and $1326 \mathrm{~mm}$. Lower annual rainfall ranging from $833 \mathrm{~mm}$ up to $1000 \mathrm{~mm}$ is observed along the river and lowlands. Relatively high rainfall is recorded in the highlands of the sub-basin. The annual maximum and minimum temperature of the sub-basin varies between $16-31.5$ and $3-16.5{ }^{\circ} \mathrm{C}$, respectively. Temperature is higher along the river with a maximum of $28-31.5^{\circ} \mathrm{C}$ and minimum of $13-16.5^{\circ} \mathrm{C}$. The sub-basin is characterized by tepid to cool moist highlands. The northwestern part of the lowlands is hot to warm moist lowlands [33].

The major soils of the sub-basin are Leptosols, Luvisols, Vertisols, Fluvisols, and Alisols. Leptosols represent the 
most widely occurring soils within the sub-basin. The second dominant soil is Luvisols. Small patches of Cambisols, Nitosols, and Rigosols are also in some parts of the basin.

\section{Socioeconomic setting}

According to the current zonal structure, the sub-basin is shared between three zones: North shoa, West shoa, and Oromia Regional State Finfine Special Zone. Muger subbasin covers 15 districts: Ejersa (Addis Alem), Walmara, Jeldu, Mulo, Sululta, Adda Berga, Meta Robi, Yaya Gulelena Debre Libanos, Wichalena Jido, Ginde Beret, Kuyu, Kutaya, Gerar Jarso, Degem, and Wara Jarso. The total population of the sub-basin is $2,442,247$ people [33]. The Muger sub-basin is predominantly rural in character, and the farmers are engaged in small-scale and subsistence mixed agriculture. The dominant sources of livelihoods in the sub-basin are crop production and livestock rearing. Map of the study area is presented in Fig. 1.

\section{Methods}

\section{Research design and methods of data collection}

The research design was based on multistage sampling procedure. In the first stage, the whole sub-basin constituting fifteen districts was grouped into three strata (Kolla, Woyina Dega, and Dega agroecological zones) based on their agroecological characteristics including the rainfall, soil, and topography. Kolla refers to an area with an altitude ranging between 500 and $1500 \mathrm{~m}$ asl, with mean annual temperature between 20 and $28{ }^{\circ} \mathrm{C}$ and annual rainfall between 600 and $900 \mathrm{~mm}$. Woyina Dega refers to an altitude ranging between 1500 and $2300 \mathrm{~m}$ asl, with mean annual temperature 16 and $20{ }^{\circ} \mathrm{C}$ and annual rainfall above $900 \mathrm{~mm}$; Dega refers to an altitude between 2300 and $3200 \mathrm{~m}$ asl, with mean annual temperature between 6 and $16{ }^{\circ} \mathrm{C}$ and mean annual rainfall above $900 \mathrm{~mm}$ [34]. Then, two districts were randomly selected from Kolla and Dega agroecological zones. Similarly, two districts were also selected from Woyina Dega agroecology using simple random sampling technique. Two districts from Woyina Dega were taken to maintain proportionality as the Woyina Dega agroecology covers larger area of the study site. In the second stage, only Peasant Associations (PAs) found in the sub-basin in each sampled districts were listed in consultation with agricultural experts in the area. This is mainly to exclude PAs which are not part of the sub-basin in that particular district. Then, four PAs were randomly selected from each selected districts. Finally, 450 sample respondents were selected from 16 PAs using random sampling technique on the basis of probability proportional to size (PPS). The sampling frame was the list of households which was obtained from the PAs administration. Households for Focussed Group Discussions (FGDs) were also drawn from each identified district, and a member of the group was identified with the help of development agents working in the area.

Both quantitative and qualitative methods of data collection were used to obtain information from the selected respondents. Quantitative data were gathered using semi-structured questionnaire. Qualitative data were obtained from FGDs to complement the information obtained through a semi-structured questionnaire in order to have a better understanding of adaptation strategies used by these farmers and barriers to adopting adaptation options. Besides data on lists of adaptation measures, this survey addressed perceived barriers to those adaptation options. Questions were also posed to investigate factors that constrain/facilitate adaptation measures to change in mean temperature and rainfall over the last two or three decades in the study area. Mean monthly temperature and precipitation from 1991 to 2016 were obtained from Ethiopian metrological station found in each sampled district.

\section{Methods of data analysis}

In order to analyze and present the data collected from sampled households, descriptive statistics (frequency, mean, maximum, minimum, and standard deviation), inferential tests (Chi-square test and one-way ANOVA test), and econometric model were used. Qualitative categorical types of data were analyzed using frequency and Chi-square test, while quantitative continuous types of variables were analyzed using one-way ANOVA, minimum, maximum, mean, and standard deviation. Qualitative information was organized and constructed coherently and analyzed based on theoretical and conceptual frameworks. After computing the descriptive statistics and inferential tests, a multinomial logistic regression model was used to identify determinants of household's adoption of adaptation options where the dependent variable was found to be multioutcome. The data analysis was conducted using Statistical Package for Social Sciences (SPSS) version 20 and Stata 12.

\section{Multinomial logit model specification}

Probit and logit models are the two most popular functional forms used in adoption modeling. These models have got desirable statistical properties as the probabilities are bounded between 0 and 1 . Apparently, adoption models could be grouped into two broad categories based on the number choices or options available to an economic agent [35]. A choice decision by farmers is 'inherently a multivariate decision. Attempting bivariate modeling excludes useful economic information contained in the interdependent and simultaneous choice decisions [36]. Since farmers decision on the use of adaptation options involves multiple response in which the 
dependent variable is discrete, it is more appropriate to treat factors which are supposed to determine farmers' decision on the use of adaptation options as a multiple choice decision. Based on this argument, the appropriate econometric model would be either multinomial logit or multinomial probit regression model. Regarding estimation, both of them estimate the effect of explanatory variables on dependent variable involving multiple choices with unordered response categories [35]. However, multinomial probit is rarely used in empirical studies due to estimation difficulty imposed by the need to solve multiple integrations related to multivariate normal distribution [37]. Moreover, a multinomial logit model is selected not only because of the computational ease but also it exhibits a superior ability to predict livelihood diversification and picking up the differences between the livelihood strategies of rural households [38]. In this study, therefore, a multinomial logit model was employed. This model makes it possible to analyze factors influencing households' choices of adaptation strategies in the context of multiple choices.

The decision of whether to use any adaptation option or not could fall under the general framework of utility maximization [39]. Following Greene [35], suppose for the $i$ th respondent faced with $j$ choices, we specify the utility choice $j$ as:

$$
U_{i j}=Z i_{j} \beta+\varepsilon_{i j}
$$

If the respondent makes choice $j$ in particular, then we assume that $U_{i j}$ is the maximum among the $j$ utilities. So the statistical model is derived by the probability that choice $j$ is made, which is:

$$
\operatorname{Prob}\left(U_{i j}>U_{i k}\right) \text { for all other } K \neq j
$$

where $U_{i j}$ is the utility to the $i$ th respondent from adaptation strategy $j, U_{i k}$ the utility to the $i$ th respondent from adaptation strategy $k$.

If the household maximizes its utility defined over income realizations, then the household's choice is simply an optimal allocation of its asset endowment to choose adaptation strategy that maximizes its utility [40]. Thus, the $i$ th household's decision can, therefore, be modeled as maximizing the expected utility by choosing the $j$ th adaptation strategy among J discrete adaptation strategies, i.e.,

$$
\max _{j}=E\left(U_{i j}\right)=f_{j}\left(x_{i}\right)+\varepsilon_{i j} ; \quad j=0 \ldots J
$$

In general, for an outcome variable with J categories, let the $j$ th adaptation strategy that the $i$ th household chooses to maximize its utility could take the value 1 if the $i$ th household chooses $j$ th adaptation strategy and 0 otherwise. The probability that a household with characteristics $\mathrm{x}$ chooses adaptation strategy $j, P_{i j}$ is modeled as:

$$
P_{i j}=\frac{\exp \left(X_{i}^{\prime} \beta_{j}\right)}{\sum_{j=0}^{J} \exp \left(X^{\prime} \beta_{j}\right)}, J=0 \ldots 3
$$

With the requirement that $\sum_{j=0}^{J} P_{i j}=1$ for any $i$, where $P_{i j}=$ probability representing the $i$ th respondent's chance of falling into category $j ; X=$ predictors of response probabilities

$\beta_{j}=$ Covariate effects specific to $j$ th response category with the first category as the reference.

Appropriate normalization that removes an indeterminacy in the model is to assume that $\beta_{1}=0$ (this arise because probabilities sum to 1 , so only $J$ parameter vectors are needed to determine the $J+1$ probabilities) [41], so that $\exp \left(X_{i} \beta_{1}\right)=1$, implying that generalized Eq. (4) above is equivalent to

$$
\begin{aligned}
& \operatorname{Pr}\left(y_{i}=j / X_{i}\right)=P_{i j}=\frac{\exp \left(X_{i} \beta_{j}\right)}{1+\sum_{j=1}^{J} \exp \left(X_{i}^{\prime} \beta_{j}\right)}, \\
& \text { for } j=0,2 \ldots J \text { and } \\
& \operatorname{Pr}\left(y_{i}=1 / X_{i}\right)=P_{i 1}=\frac{1}{1+\sum_{j=1}^{J} \exp \left(X_{i}^{\prime} \beta_{j}\right)},
\end{aligned}
$$

where $y=$ A polytomous outcome variable with categories coded from $0 . . . J$.

Note The probability of $P_{i 1}$ is derived from the constraint that the $J$ probabilities sum to 1 . That is, $p_{i 1}=1-\sum p_{i j}$.

The multinomial logistic models crucially depend on the independence of irrelevant alternatives (IIA) assumption in order to obtain unbiased and consistent parameter estimates. This assumption requires the likely of the household's using a certain adaptation options need to be independent of other alternative adaptation options used by the same household's. Hausman test was used to test the validity of the IIA assumption.

The estimated cofficients of multinomial logit model provide only the direction of effect of independent variables on dependent variables, but estimate neither represent the actual magnitude of change nor probabilities [42]. Thus, the Stata version 12 was used to generate the parameter estimates (marginal effect). The marginal effects measure the expected change in the probability of a particular choice being made with respect to a unit change in an independent variable [35].

\section{Definition of variables and hypothesis}

The dependent variable in this study is the choice of an adaptation option that is listed in Fig. 2. The potential explanatory variables, which were hypothesized to influence farmers' use of adaptation options in response to climate variability and change and considered in the 


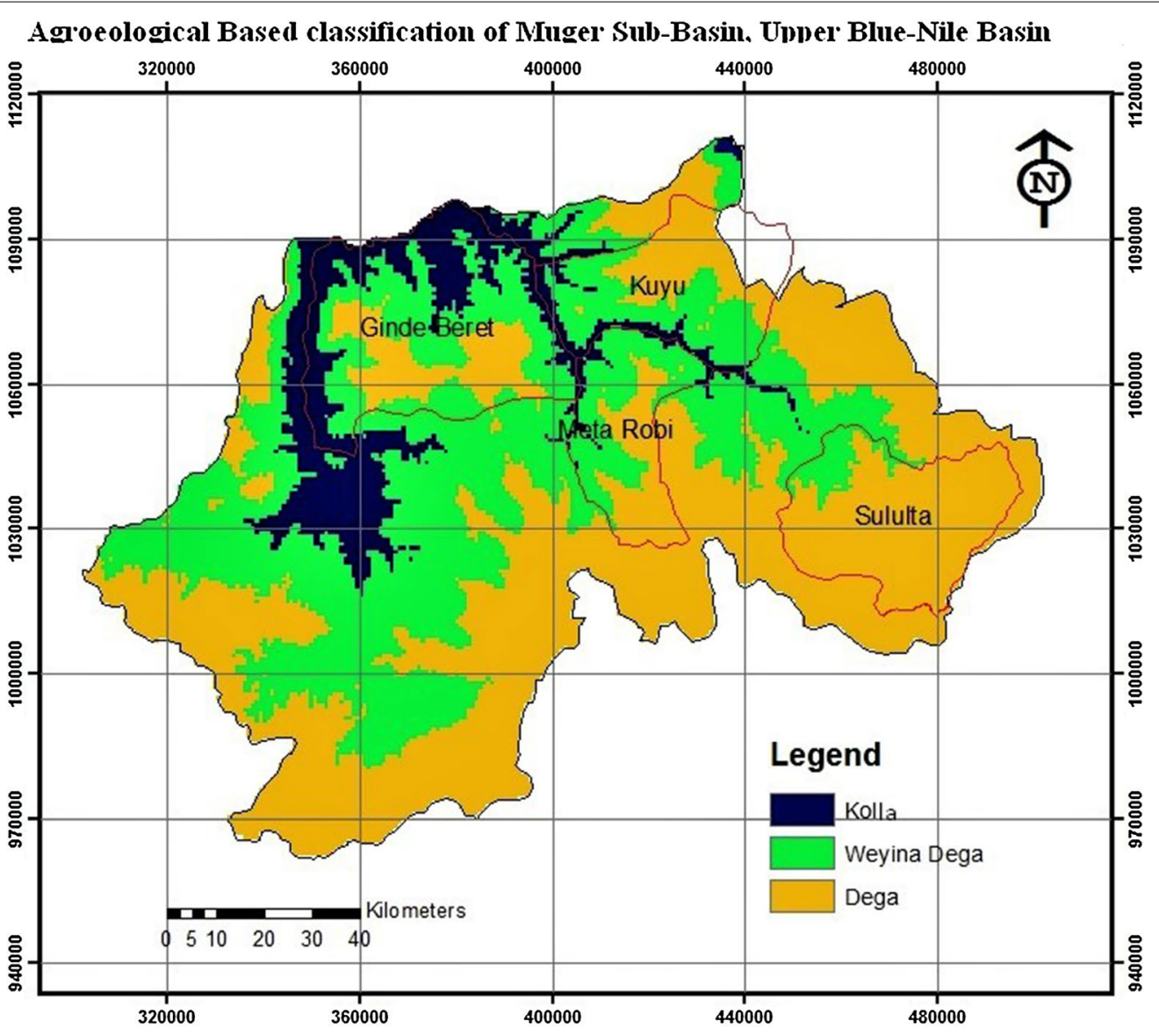

ADMINISTRATIVE MAP OF ETHIOPIA

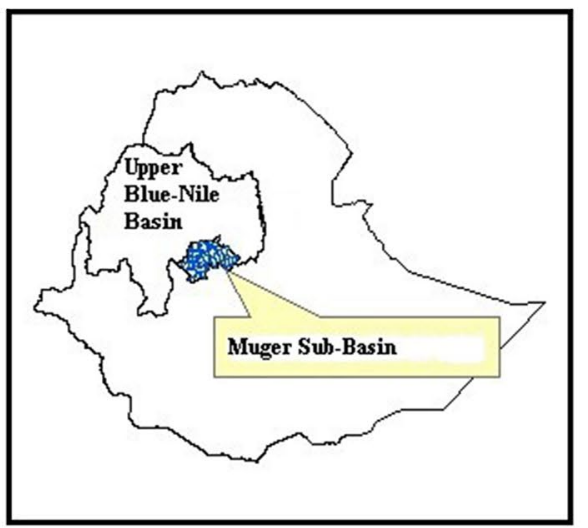

MUGER SUB-BASIN

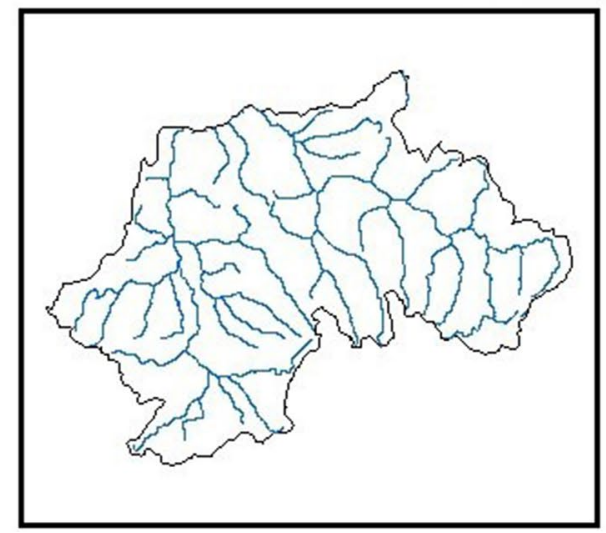

Fig. 1 Agroecology-based classification of Muger sub-basin of the Blue Nile basin of Ethiopia

analysis, are often classified as personal, physical, socioeconomic, institutional, and climate factors [43, 44]. These variables include age of the household head, gender of the household head, education status, and family size, membership in the social group, access to extension service, access to credit service, and climate warning system, agroecology, livestock ownership, the occurrence of drought and flood, and land cultivated. Table 1 presents the description, definition and unit of measurment for both dependent and independent variables. 


\section{Family size}

The empirical adoption literature shows that household size has mixed impacts on farmers' adoption of agricultural technologies. Larger family size positively influences farmers to take up labor-intensive adaptation measures like soil and water conservation (SWC) and irrigation that demand labor which is a critical problem in a peak period of production and livestock rearing $[45,46]$. Alternatively, a large family might be forced to divert part of its labor force into non-farm activities to generate more income and reduce consumption demands [42]. We hypothesize that SWC and small-scale irrigation are more labor intensive and hence we expect family size to have a positive influence on the adoption of such adaptation measures. Similarly, this variable is expected to have a positive effect on the use of diversified livelihood options.

\section{Age of the household head}

The influence of age on adoption of SWC is unclear. Some studies found a positive relationship between age and conservation investment. This indicates that the likelihood of adoption of conservation practices is more among older farmers than among the younger ones, perhaps because older farmers could adopt SWC because they have more experience that helps them to perceive erosion problems [43, 47]. Conversely, older farmers could be less willing to bear the risk of investing in SWC due to their shorter planning horizons $[45,46]$. In this study, we hypothesize that age of the household head has both positive and negative impacts on adaptation measures. Empirical studies by Arega et al. [48] and Gebreyesus [49] showed that age of the household head negatively related to farmers decision to diversify to non-farm and off-farm activities. Thus, age is hypothesized to influence the decision to diversify livelihood options.

\section{Gender of the household head}

It is a dummy variable that takes 1 if the household head is male, 0 otherwise. Many previous literature on adaptation, the influence of gender on adoption of adaptation measures are mixed. Female farmers have been found to be more likely to adopt natural resource management and conservation practices $[45,50]$. However, some studies found that male household heads had a better opportunity to take an adaptation measure than female household by involving on agronomic practices (such as crop diversification and use of drought-tolerant crop species) and by adopting SWC measures and irrigation to their farm [51, 52]. For instance, Asfaw and Admassie [51] noted that male-headed households are often considered to be more likely to get information about new technologies and take risky businesses than female-headed households. We hypothesize that female- and male-headed households differ significantly in their ability to adapt to climate change because of major differences between them in terms of access to assets, education, and other critical services such as credit, technology, and input supply.

\section{Farm size}

It is a continuous variable defined as the years of schooling attained by the household heads. In most of the adoption studies, it has been shown that education is an important factor that positively influences adoption decisions [42, 46, 53-55]. These studies have shown that better education and more farming experience increase farmers' ability to get and use of information and improve awareness of potential benefits and willingness to participate in local natural resource management and conservation activities. Educated and experienced farmers are expected to have more knowledge and information about climate change and agronomic practices that they can use in response [56]. We expect that improved knowledge and farming experience will positively influence farmers' decisions to take up adaptation measures.

\section{Farm size}

Empirical adoption studies have found mixed effects of farm size on adoption of SWC. For example, a study on soil conservation measures and irrigation in Ethiopia found that farmers with larger farms were found to have more land to allocate for constructing soil bunds, stone bunds, check dams, and improved cutoff drains and motivate to use irrigation $[47,53,57,58]$. Similarly, Gbetibouo [59] revealed that farm size is positively correlated with the probability of choosing irrigation as an adaptation measure. On the other hand, Nyangena [60] found that farmers with a small area of land were more likely to invest in soil conservation than those with a large area. It is also supported by the study conducted by [32]. According to their argument, the need for specific adaptation option (i.e., SWC measures) to climate variability and change is dictated by characteristics of the plot than the size of the farm. This means that it is not the size of the farm. Empirical studies have shown that the area of land owned by the household has a negative correlation with the likelihood of diversifying to non-farm and off-farm activities $[48,61]$. Therefore, farm size to have a positive role in the decision to use irrigation is hypothesized. On the other hand, farm size was expected to negatively affect the use of different livelihood diversification options.

\section{Access to agricultural extension services}

Extension services are an important source of information on agronomic practices as well as on climate. Extension education is found to be an important factor motivating 
an increased intensity of the use of specific SWC practices and irrigation use because access to extension services and information help farmers to have better understanding of the land degradation problem and soil conservation practices and hence may perceive SWC practices to be profitable $[42,43,46,53]$. Thus, extension service is hypothesized to be promoting decision to use SWC practices, agronomic practices, and irrigation use. This study postulates that the availability of better climate and agricultural information helps farmers make comparative decisions among alternative crop management practices and hence choose the ones that enable them to cope better with changes in climate [62].

\section{Access to credit}

Several studies have shown that access to credit is an important determinant enhancing the adoption of various technologies [42, 52, 59, 62]. Deressa et al. [32] and Gbetibouo [59] reported that farmers with more financial and other resources at their disposal are able to make use of all their available information to invest on the use of irrigation, use of agricultural inputs, use of drought-tolerant crop species, use of SWC, and take up livelihood diversification in response to changing climatic and other conditions. Credit provision has the advantage to solve financial constraints to meet their need to change their practices to suit the forecasted climate change. Thus, it is hypothesized that access to credit has a positive effect on the use of irrigation, use of SWC measures, use of drought-tolerant crop species, and use of non-farm and off-farm activities.

\section{Market access}

Distance to the nearest market is used to proxy for availability of input and output markets. It is another important factor affecting adoption of agricultural technologies. The households located further away from markets are found to adopt lesser adaptation practices [30, 56, 63, 64]. Input markets allow farmers to acquire the inputs they need such as different seed varieties, fertilizers, and irrigation technologies. At the other end, access to output markets provides farmers with positive incentives to produce cash crops that can help improve their resource base and hence their ability to respond to changes in climate [30]. Maddison [56] observed that long distances to markets decreased the probability of farm adaptation in Africa and that markets provide an important platform for farmers to gather and share information. Lapar and Pandely [65] found that in the Philippines access to markets significantly affected farmers' use of conservation technologies. Piya et al. [66] showed that in Nepal distance to markets negatively and significantly affected the use of SWC technologies. It is expected that the households located further away from the road are less likely to adopt livelihood diversification strategies, varietal selection, and the construction of tanks, but more likely to depend on traditional coping strategies.

\section{Livestock ownership in TLU}

Previous studies have shown mixed evidence about the relationship between livestock ownership and farmers' decision in relation to SWC investment [42, 47, 55, 58]. Amsalu and De Graaff [47] showed that livestock ownership has negative influence to adopt stone terrace. On the contrary, more specialization in livestock negatively influences the use of SWC by reducing the economic impact of soil erosion. Hence, the effect of the size of livestock holding on conservation decision is difficult to hypothesize a prior. Livestock holding negatively influences household's choice of non-farm and off-farm activities that means the farmer with lower livestock holding would be obliged to diversify livelihoods into off- and non-farm in order to meet needs $[67,68]$. Therefore, it is hypothesized to have a negative relationship with diversifying livelihood options.

\section{Access to weather information}

Smallholder farmers require different types of climate information during each stage of the agricultural production process in order to adapt to climate variability and change. Major climate change information includes early warning signals, weather forecasts, pest attacks, input management, cultivation practices, pest and disease management, and prices [69-71]. Nhemachena and Hassan [72] reported that better access to weather information has a positive influence on the decision to invest in SWC measures, use of irrigation, use of drought-tolerant crop varieties, and diversify livelihood options in response to climate change problem. In the same way, Deressa et al. [52] found that access to information increases the likelihood of using SWC measures and different crop varieties to adapt climate change. The effect of access to weather information on the decision to use SWC measures, irrigation, drought-tolerant crop varieties, and livelihood diversification is expected to be positive.

\section{Membership in a social group}

Membership to social groups or organizations enables farmers to acquire information on proper agronomic practices, credits, and productive inputs as well as attend training and workshops at which stakeholders meet and exchange ideas. Self-help grouping and formation of cooperatives are a more reliable and pragmatic means of achieving social capital and ensuring dissemination and adoption of innovative technology [73, 74]. Tafa et al. [44] found that being a member of a social group increased 
the probability of adapting climate variability and change using conservation agriculture, drought-tolerant varieties, and irrigation. Thus, membership in social groups positive effect on adoption of adaptation options in response to climate change impact is hypothesized.

\section{Agroecological setting}

In Ethiopia, Kolla agroecology (lowland) is characterized by relatively hotter and drier climate, whereas Weyina Dega (middle land) and Dega agroecology (highland) are wetter and cooler [32]. Evidence revealed that farmers living in different agroecological settings have their own choice of adaptation methods [32, 75, 76]. For instance, Deressa et al. [32] observed that farming in the Kolla zone significantly increases the probability of SWC practices, compared to farming in Weyina Dega. However, farming in Kolla significantly reduces the probability of using different crop varieties, planting trees, and irrigation as compared to farming in weyna Dega. Hence, agroecology was hypothesized to have a positive or negative effect on household's adoption decision on climate change adaptation options.

\section{Results and discussion}

\section{Adaptation strategies of smallholder farmers to climate} change and variability

Based on data from a comprehensive survey of agricultural households across three agroecologies in Muger River sub-basin of the Blue Nile River Basin, this section briefly summarizes farmers' adaptation strategies in response to climate variability and change. In this survey, farmers were asked questions about what measures and practices they have typically used in order to cope with the negative impact of climate variability and changes over the past 5 years. The results show that adaptation strategies farmers used include using stone bund; soil bund; check dam; terrace; small-scale irrigation; drought-tolerant and/or improved crop varieties; crop diversification; on-farm activity, non-farm activity, and off-farm activity. For the purpose of this analysis, the identified adaptation strategies are combined into five categories including the 'no adaptation' category for the convenience of model analysis. In this study because of their close relation, the above four adaptation strategies (namely stone bund, soil bund, check dam, and terrace) are grouped into one single component of SWC measure. Similarly, use of an on-farm activity, non-farm activity, and off-farm activity is merged together into livelihood diversification component. Moreover, use of drought-tolerant crop varieties, crop diversification, and improved crop varieties has merged together and categorized as an agronomic practice.

Figure 2 shows that the use of SWC measures $(28.7 \%)$ and small-scale irrigation (27.4\%) are the two most widely used adaptation strategies in the study area. Most of the smallholder farmers use stone bund, soil bund, check dam, and terrace. The use of these strategies was found to reduce soil erosion associated with short but heavy rains which are usually common in the study areas. It is also disclosed that because of the unreliable and erratic pattern of rainfall and repeated drought, farmers started using small-scale irrigation schemes over their farm. We

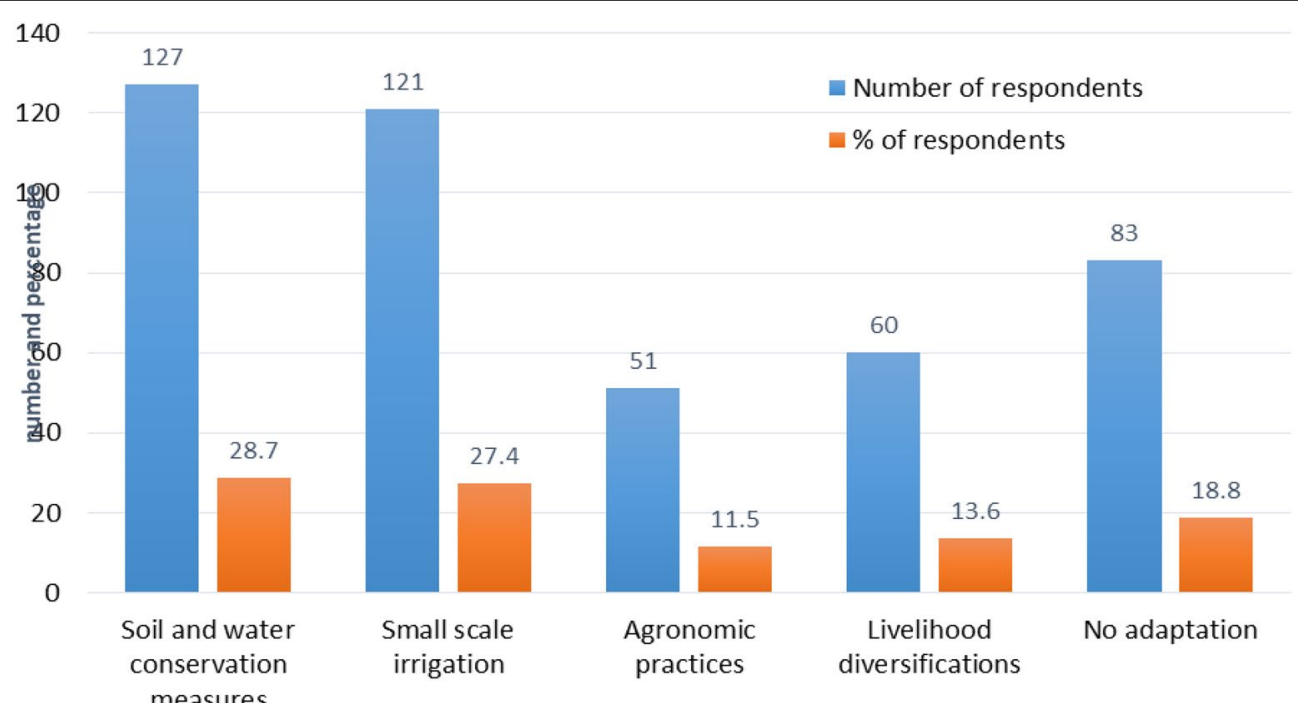

Adaptation options

Fig. 2 Adaptation strategies used by smallholder farmers 
also observed that diverted streams, pond construction, and use of water pump are found to be the major means for small-scale irrigation in the Muger River sub-basin. Farmers have also been using different livelihood strategies as a vitally important adaptation strategy in the face of the uncertainties due to the implications of climate variability and change (Table 1 ).

In response to the adverse effects caused by climate variability and change, smallholder farmers have been diversifying their sources of livelihood with an understanding of more diversified livelihood strategies lead them both enhance incomes and spread the risk for smallholder farmers. About $14 \%$ of the survey respondents are engaged in diversifying their livelihood strategies using off-farm and/or non-farm activities in addition to their farming practice. The result shows that smallholder farmers in the study area diversified their livelihood strategies from depending on farming activities only to off-farm and/or non-farm income-generating activities. Using agronomic practices (13.6\%) is another strategy that is found to be used by smallholder farmers in adapting to the effects of variability and change as well as resultant changes in crop pest and disease pressures. To minimize the risk from the total loss of crop production and to increase crop productivity, farmers employed diversifying crops grown on the same plot of farm, drought-tolerant crop variety, and improved crop variety. These strategies are important in managing current climate risks, particularly for subsistence agricultural communities of which majority are smallholder farmers. Nevertheless, the number of farmers who did not adjust their farming practices in response to climate variability and change (18.8\%) is found to be large. However, this figure is relatively low compared to similar data collected from Ethiopia where $37 \%$ of farm households did not adapt [77].

Table 1 Descriptions, definition, and values of variables used in empirical model

\begin{tabular}{|c|c|c|}
\hline Variable & Definition & Value and unit of measurement \\
\hline \multicolumn{3}{|l|}{ Dependent variable } \\
\hline Adaptation options & Adaptation options & $\begin{array}{l}\text { It is a categorical variable which takes the value } 0 \text { for not } \\
\text { using any adaptation option, } 1=\text { using soil and water } \\
\text { conservation measure, } 2=\text { using small-scale irrigation, } \\
3=\text { adopting agronomic practices, and } 4=\text { using dif- } \\
\text { ferent livelihood diversification strategies }\end{array}$ \\
\hline \multicolumn{3}{|l|}{ Independent variable } \\
\hline AGROECOLOGY & Agroecology & $\begin{array}{l}\text { It is categorical variable which takes the value } 0 \text { for Kolla, } \\
1 \text { for Woyina Dega, and } 2 \text { for Dega agroecology }\end{array}$ \\
\hline GENDERHH & Gender of the household head & $\begin{array}{l}\text { It is dummy variable which takes the value } 1 \text { for male and } \\
0 \text {, otherwise }\end{array}$ \\
\hline AGEHH & Age of the household head & It is a continuous variable measured in years. \\
\hline EDUCATION & Education status of the household head & It is continuous variable measured in years of schooling \\
\hline FAMILY SIZE & Number of family members & $\begin{array}{l}\text { Refers to the number of members who are currently liv- } \\
\text { ing within the family }\end{array}$ \\
\hline SOCIAL CAPITAL & $\begin{array}{l}\text { Number of social groups which a household head has } \\
\text { a membership }\end{array}$ & $\begin{array}{l}\text { It is continuous variable measured in number of social } \\
\text { groups that a household head is membership }\end{array}$ \\
\hline $\begin{array}{l}\text { ACCESS TO EXTENSION SER- } \\
\text { VICES }\end{array}$ & Access to extension services & $\begin{array}{l}\text { It is a dummy variable, which takes the value } \\
1 \text { if the farm household access to extension service, and } 0 \\
\text { otherwise }\end{array}$ \\
\hline ACCESS CREDIT & Access to credit services & $\begin{array}{l}\text { It is a dummy variable, which takes the value } \\
1 \text { if the farm household access to credit and } 0 \\
\text { otherwise }\end{array}$ \\
\hline WARNING SYSTEM & $\begin{array}{l}\text { Receive a warning about the flood/drought before if } \\
\text { happened }\end{array}$ & $\begin{array}{l}\text { It is a dummy variable that takes the value } 1 \text { if the house- } \\
\text { hold receives a warning about drought/floods before it } \\
\text { occurs, and } 0 \text { otherwise }\end{array}$ \\
\hline LIVESTOCKTLU & Number of livestock owned by the household & $\begin{array}{l}\text { It is continuous variable measured in TLU using conver- } \\
\text { sion factors (Annex) }\end{array}$ \\
\hline CROP FAILURE & $\begin{array}{l}\text { Frequency of number of droughts over the past } \\
25 \text { years }\end{array}$ & It is continuous variable measured in number \\
\hline CULTIVLAND & Hectare of land cultivated & It is continuous variable measured in hectare \\
\hline MARKET DISTANCE & Distance from the nearest market & $\begin{array}{l}\text { It is a continuous variable measured in walking hours } \\
\text { from home to the nearest market }\end{array}$ \\
\hline
\end{tabular}




\section{Comparison of adopters and non-adopters of adaptation options}

Tables 2 and 3 present the continuous and dummy explanatory variables that are supposed to influence adoption of adaptation options that smallholder farmers pursue in response to the adverse effect of climate variability and change. These variables are grouped into demographic characteristics, farm characteristics, and institutional factors.

\section{Household demographic characteristics}

The sample population is made of $84.8 \%$ male and $15.2 \%$ women. This large number of men is due to the fact that men are the heads of the households as custom demands are answerable to anyone who comes to the house. It is also reported that $99.2 \%$ of households that adopt SWC measures are found to be male-headed households, whereas $56 \%$ of non-adopters of any of the adaptation option are found to be female-headed households. The Chi-square test shows that differences of the gender of the household head are statistically significant $(p<0.000)$ among the adopters of any of the adaptation option and non-adopters of the adaptation options. Age of the household head influences overall adoption of adaptation options in response to climate variability and change.

Table 2 Differences of continuous explanatory variables between adopter and non-adopter households using one-way ANOVA

\begin{tabular}{|c|c|c|c|c|c|c|c|}
\hline \multirow[t]{2}{*}{ Continuous variables } & \multicolumn{7}{|c|}{ Adaptation options } \\
\hline & No adaptation & Irrigation & $\begin{array}{l}\text { Agronomic } \\
\text { practice }\end{array}$ & $\begin{array}{l}\text { Livelihood } \\
\text { diversification }\end{array}$ & $\begin{array}{l}\text { Soil and water } \\
\text { conservation }\end{array}$ & $\begin{array}{l}\text { Average } \\
\text { mean }\end{array}$ & Sig. \\
\hline Mean age of $\mathrm{HH}$ & 42.72 & 45.1 & 45.14 & 46.38 & 47.28 & 45.46 & 0.138 \\
\hline Mean of education of the $\mathrm{HH}$ & 1.55 & 4.72 & 2.84 & 2.08 & 3.33 & 3.15 & 0.000 \\
\hline Mean of family size & 5.08 & 5.90 & 6.43 & 5.93 & 6.20 & 5.9 & 0.000 \\
\hline Mean of number of social capital & 0.89 & 4.26 & 2.51 & 2.3 & 2.51 & 2.74 & 0.000 \\
\hline $\begin{array}{l}\text { Mean of distance to market in walking } \\
\text { hours }\end{array}$ & 1.88 & 1.30 & 1.5 & 1.42 & 1.96 & 1.64 & 0.000 \\
\hline Mean of livestock in TLU & 4.92 & 8.54 & 6.17 & 4.77 & 6.51 & 6.5 & 0.000 \\
\hline $\begin{array}{l}\text { Mean of number of crop failed } \\
\text { experience }\end{array}$ & 3.51 & 7.17 & 8.14 & 7.02 & 7.09 & 6.55 & 0.000 \\
\hline Mean of farm size in ha & 0.98 & 1.84 & 1.15 & 1.21 & 1.89 & 1.47 & 0.000 \\
\hline
\end{tabular}

Table 3 Differences of dummy explanatory variables for adopter and non-adopter households

\begin{tabular}{|c|c|c|c|c|c|c|c|c|}
\hline \multirow[t]{2}{*}{ Dummy variables } & \multicolumn{8}{|c|}{ Adaptation options } \\
\hline & No adaptation & irrigation & $\begin{array}{l}\text { Agronomic } \\
\text { practice }\end{array}$ & $\begin{array}{l}\text { Livelihood } \\
\text { diversification }\end{array}$ & $\begin{array}{l}\text { Soil and water } \\
\text { conservation }\end{array}$ & Percentage & Chi-square & Sig. \\
\hline \multicolumn{9}{|l|}{ Agroecology } \\
\hline Kolla & 43.4 & 6.6 & 37.3 & 21.7 & 52.8 & 32.4 & 78.543 & 0.000 \\
\hline Woyina Dega & 44.6 & 53.7 & 45.1 & 55 & 33.1 & 45.2 & & \\
\hline Dega & 12 & 39.7 & 17.6 & 23.3 & 14.2 & 22.4 & & \\
\hline \multicolumn{9}{|l|}{ Gender of the $\mathrm{HH}$} \\
\hline Female & 59 & 1.7 & 11.8 & 15 & 0.8 & 15.2 & 162.266 & 0.000 \\
\hline Male & 44 & 98.3 & 88.2 & 85 & 99.2 & 84.8 & & \\
\hline \multicolumn{9}{|c|}{ Access to extension service } \\
\hline No & 71.1 & 29.8 & 17.6 & 23.3 & 18.9 & 32.1 & 75.307 & 0.000 \\
\hline Yes & 28.9 & 70.2 & 82.4 & 76.7 & 81.1 & 67.9 & & \\
\hline \multicolumn{9}{|l|}{ Access to credit } \\
\hline No & 66.3 & 16.5 & 35.3 & 38.3 & 31.5 & 35.3 & 54.563 & 0.000 \\
\hline Yes & 33.7 & 83.5 & 64.7 & 61.7 & 68.5 & 64.7 & & \\
\hline \multicolumn{9}{|c|}{ Access to warning information } \\
\hline No & 65.1 & 16.5 & 45.1 & 23.3 & 15.7 & 29.6 & 78.649 & 0.000 \\
\hline Yes & 34.9 & 83.5 & 54.9 & 76.7 & 84.3 & 70.4 & & \\
\hline
\end{tabular}


Through experience, farmers perceive and understand the impact of climate variability and change on agricultural production, environment, and social issues. The mean age of sample household heads was 45.46 with a standard deviation of 12.67 . The statistical analysis reveals that there is no significant difference in the mean age of sample household heads between adopters and non-adopters of adaptation option. The mean family size for the sample population is found to be 5.9 with a standard deviation of 2.021. This mean family size is above the national average family size of 4.7 persons per household [78]. Furthermore, the mean family size for non-adopter households and adopter of agronomic practices is found to be 5.08 , and 6.43 , respectively. The mean difference of family size among the groups is statistically significant $(p<0.000)$. Average of highest grade attained is 3.15. The average years of formal education of adopter of small-scale irrigation and non-adopters of any adaptation option are estimated to be 4.72 and 1.5, respectively, and one-way ANOVA result shows that the mean difference between non-adopters and adopters of any adaptation option is statistically significant $(p<0.000)$.

\section{Farm characteristics}

The average cultivated landholding of the total sample household heads is 1.47 ha with an average size of 0.98 and 1.89 ha for non-adopters and adopters of SWC measure households, respectively. The result further reveals that the mean difference between adopters and non-adopters of any of the adaptation option is found to be statistically significant at less than $1 \%$ significance level. Although landholding size is significantly different between adopters and non-adopters of adaptation options, it is noted that the mean land ownership of the sample households is larger than the national average of landholding of which less than 1 ha. Livestock is an important component of the farming system in the study area. A vast majority of the sample households included in this survey own animals of a different kind. The average livestock holding for sample households in Tropical Livestock Unit is found to be 6.5. The average livestock holding for non-adopters and adopters of small-scale irrigation are found to be 4.92 and 8.54, respectively. One-way ANOVA result reveals that livestock ownership is statistically significant (at less than $1 \%$ ) between adopter groups and non-adopter. This leads to the conclusion that a household who own more livestock is more likely to adopt small-scale irrigation as compared to their counterparts.

\section{Institutional factors}

Institutional support like credit facilities, market accessibility, extension services, timely input supply, and availability of agricultural technologies, irrigation scheme, and other rural infrastructure development is central to development. The survey result indicates that from the total sample household heads about $67.9 \%$ of households have access to extension services, while the remaining $32.1 \%$ of sample population do not have access to extension. The result further indicates that from the total adopters of agronomic practices, $82.4 \%$ of the households have access to extension services. On the other hand from the total of non-adopter households, only $28.9 \%$ have access to those extension services. The Chi-square analysis reveals that difference among adopters and non-adopters of different adaptation options is found to be significant at less than $1 \%$ significance level. Credit availability has also a paramount importance to improve the ability of the households at critical times of year to buy inputs. Availability of credit and modern inputs is integral parts of the extension system required to increase agricultural production through the use of modern agricultural technologies like fertilizer, improved seeds, and farm implements. As reported from the survey result, about $64.7 \%$ of sample households get credit either in the form of cash or in kind from government, informal local institutions, and private money lenders and from friends and relatives, while $35.3 \%$ of sampled households do not have access to credit from any credit and saving institutions. It is noticed that from a total of small-scale irrigation adopters, $83.5 \%$ of households get credit. On the other hand, only $33.7 \%$ of households get access to credit from a total of non-adopters. It is also reported that access to credit is statistically different among adopter and non-adopter categories.

Membership in the existing local organizations indicates to a certain level the social capital a farmer possesses. This social capital has the potential to internalize economic externalities and help the adoption of adaptation options in response to climate variability and change [79]. Table 2 depicts that on average farmers are a member of 2.74 social groups. The average number of the social group that the sample households are a membership for non-adopters and adopters of small-scale irrigation is found to be 0.89 and 4.26 , respectively. The statistical analysis shows that membership to social groups is significantly different between adopters and non-adopter of any of adaptation options $(p<0.000)$. Access to early warning to climate change is another important factor determining adoption of adaptation options in response to the adverse effect of climate change. The survey result indicates that from the total sample households, $29.6 \%$ of households get early warning information, while large proportion (70.4\%) of households do not get early warning information that would have been helpful to make preparedness to reduce the 
adverse impact of climate change and variability. The Chi-square result reveals that difference in access to early warning information is statistically significant between users and non-users of adaptation options. Although the information of early warning is broadcasted on the radio, such warning is limited to farmers who have a radio, and not available to remote areas of the study sites. Another important variable that has a strong association with the adoption of adaptation options is walking distance from the home of the household to the marketplace. A significant relationship is observed between distance to the market and adoption of adaptation options at less than $1 \%$ significance level.

\section{Determinants of adoption of climate change adaptation measures}

To estimate the multinomial logit model, we considered the first category (no adaptation) as a base category. Moreover, multicollinearity was checked using variance inflation factor (VIF) and contingency coefficients (CC). The results from VIF values have shown that variance inflation factors for all variables are less than 10 , which indicate all the continuous explanatory variables have no serious multicollinearity problem. Similarly, values of the CC have shown no multicollinearity problem among dummy variables. Based on the above test both the hypothesized continuous and dummy variables were retained in the model. Prior to running the multinomial logit model, we used Hausman test and the seemingly unrelated post-estimation procedure (SUEST) to test for the validity of the independence of the irrelevant alternatives (IIA) assumptions. The results of the tests show that both tests failed to reject the null hypothesis of independence of the climate change adaptation options, suggesting that the multinomial logit (MNL) specification is appropriate to model climate change adaptation practices of smallholder farmers. The likelihood ratio statistics as indicated by Chi-square statistics are highly significant $(p<0.01)$, suggesting the model has a strong explanatory power. Table 4 presents the estimated coefficients of the MNL model, along with the levels of significance.

It is noted that the parameter estimates of the MNL model provide only the direction of the effect of the independent variables on the dependent (response) variable and lacks to represent the actual magnitude of change or probabilities. Thus, the marginal effects from the MNL, which measure the expected change in the probability of a particular choice being made with respect to a unit change in an independent variable, are reported and discussed. As mentioned earlier, this analysis uses the estimated coefficients of no adaptation as the base category and evaluates the other choices as alternatives to this option. Table 5 presents the marginal effects along with $p$ values. Multinomial logistic regression model results show that most of the explanatory variables determined adoption of adaptation options are as expected.

\section{Gender of the household head}

Agronomic practice, livelihood diversification strategies, and SWC are significantly affected by gender of the household head. It is also observed that small-scale irrigation is not influenced by gender. The results have shown that gender was negatively and significantly related to the adoption of agronomic practices and livelihood diversification strategies at 10 and $1 \%$ significance level, respectively. The results indicate that being maleheaded households more likely reduce practicing agronomic practices by $9.4 \%$, and reduce to diversify their livelihood options by $16.5 \%$. The negative effect of gender of the household heads on adoption of agronomic practices and livelihood diversification strategies is probably due to the fact that women do much of non-agricultural works in the study area. These results are in conformity with the prior argument by Nhemachena and Hassan [72] which revealed that female-headed households are more likely to take up climate change adaptation methods. However, it is in contrary to the previous argument by showing that male-headed households had better opportunity to take an adaptation measure than female household mainly due to cultural and social barriers in the area that limits women's access to land and information using agronomic practices [51, 52].

Conversely, male-headed households adapt more readily to climate change using SWC. Male-headed households were about $36 \%$ more likely to use SWC measures. This may be explained by the fact that constructing SWC measures needs substantial labor and female-headed households in Ethiopia are constrained with labor availability than male-headed households. This study follows the prior argument that indicates male-headed households are more likely to take up the SWC measures as SWC structures are labor intensive [51, 52]. The important policy implication is the call to target women farmers and to increase their uptake of adaptation measures.

\section{Education status of the household head}

This study shows the positive impact of education on farmers' decision to adopt small-scale irrigation and livelihood diversification. The results show that education has no significant influence on use of agronomic practices and SWC measures. It is apparent that educated farmers are more likely to use small-scale irrigation which has a potential to reduce the adverse effect of extreme drought on agricultural production and productivity particularly in moisture-stressed areas. This study reveals that education significantly increases small-scale irrigation 
Table 4 Parameter estimates of the multinomial logit climate change adaptation model

\begin{tabular}{|c|c|c|c|c|c|c|c|c|}
\hline \multirow[t]{2}{*}{ Explanatory variables } & \multicolumn{2}{|l|}{ Irrigation } & \multicolumn{2}{|c|}{ Agronomic practices } & \multicolumn{2}{|c|}{ Livelihood diversification } & \multicolumn{2}{|c|}{$\begin{array}{l}\text { Soil and water conser- } \\
\text { vation }\end{array}$} \\
\hline & Coefficients & P level & Coefficients & Plevel & Coefficients & Plevel & Coefficients & $P$ level \\
\hline \multicolumn{9}{|l|}{ AGROECOLOGY } \\
\hline 2 & 0.04382 & 0.969 & -0.81489 & 0.429 & -0.00684 & 0.995 & $-1.94269^{* *}$ & 0.058 \\
\hline 3 & -1.6309 & 0.260 & $-3.09980^{* * *}$ & 0.027 & -2.06575 & 0.135 & $-4.11506^{* * *}$ & 0.003 \\
\hline GENDERHH & $4.5784^{* * *}$ & 0.001 & $3.39037^{* * *}$ & 0.002 & $2.92271^{* * *}$ & 0.007 & $6.31437^{* * *}$ & 0.000 \\
\hline AGEHH & 0.02474 & 0.530 & 0.02838 & 0.465 & 0.03507 & 0.363 & 0.02153 & 0.571 \\
\hline EDUCATION & $0.35660^{* * *}$ & 0.002 & 0.15505 & 0.162 & 0.09720 & 0.389 & 0.16838 & 0.123 \\
\hline FAMILYSIZE & 0.02708 & 0.897 & 0.20196 & 0.323 & 0.15449 & 0.444 & 0.06125 & 0.761 \\
\hline Social capital & $3.5246^{* * *}$ & 0.000 & $2.62318^{* * *}$ & 0.000 & $2.77039^{* * *}$ & 0.000 & $2.79201^{* * *}$ & 0.000 \\
\hline TRAINING & $2.2494^{* * *}$ & 0.010 & $2.81760^{* * *}$ & 0.001 & $2.46013^{* * *}$ & 0.004 & $2.66200^{* * *}$ & 0.002 \\
\hline CREDIT & $2.3048^{* * *}$ & 0.013 & 1.30769 & 0.148 & 1.21670 & 0.173 & 1.29698 & 0.148 \\
\hline DISTMARKET & -0.3730 & 0.545 & -0.66452 & 0.276 & -0.49368 & 0.418 & 0.06126 & 0.917 \\
\hline WARNING & $2.2758^{* * *}$ & 0.011 & 1.08831 & 0.203 & $2.17846^{* * *}$ & 0.012 & $2.47294^{* * *}$ & 0.004 \\
\hline LIVESTOCKTLU & -0.06469 & 0.600 & -0.03279 & 0.787 & $-0.22183^{* *}$ & 0.073 & -0.07275 & 0.547 \\
\hline CROP FAILURE & $0.90076^{* * *}$ & 0.000 & $1.00497^{* * *}$ & 0.000 & $0.86159^{* * *}$ & 0.000 & $0.84016^{* * *}$ & 0.000 \\
\hline CULTIVLAND & 0.75052 & 0.275 & -0.17688 & 0.797 & 0.35875 & 0.600 & 0.80477 & 0.231 \\
\hline _cons & $21.7216^{* * *}$ & 0.000 & $-16.0392^{* * *}$ & 0.000 & $-15.528^{* * *}$ & 0.000 & $-18.4650^{* * *}$ & 0.000 \\
\hline
\end{tabular}

Base category no adaptation

Number of obs. 442

$\operatorname{LR} X^{2}(56) 642.74$

Prob $>x^{2} 0.0000$

Log likelihood - 362.53853

Pseudo-R2 0.4699

***,** Significant at 1 , and 5 probability level, respectively

Table 5 Marginal effects from the multinomial logit of climate change adaptation model

\begin{tabular}{|c|c|c|c|c|c|c|c|c|}
\hline \multirow{2}{*}{$\begin{array}{l}\text { Adaptation options } \\
\text { Explanatory variables }\end{array}$} & \multicolumn{2}{|l|}{ Irrigation } & \multicolumn{2}{|c|}{ Agronomic practices } & \multicolumn{2}{|c|}{ Livelihood diversification } & \multicolumn{2}{|c|}{$\begin{array}{l}\text { Soil and water conserva- } \\
\text { tion }\end{array}$} \\
\hline & Coefficients & $P$ level & Coefficients & Plevel & Coefficients & $P$ level & Coefficients & Plevel \\
\hline \multicolumn{9}{|l|}{ AGROECOLOGY } \\
\hline 2 & $0.14576 * * *$ & 0.002 & 0.00949 & 0.831 & $0.10303 * *$ & 0.013 & $-0.27490 * * *$ & 0.000 \\
\hline 3 & $0.19773 * *$ & 0.001 & -0.02721 & 0.603 & 0.07924 & 0.154 & $-0.31924 * * *$ & 0.000 \\
\hline GENDERHH & -0.02002 & 0.860 & $-0.09392^{*}$ & 0.092 & $-0.16525 * * *$ & 0.003 & $0.35996 * * *$ & 0.013 \\
\hline AGEHH & -0.00015 & 0.916 & 0.00032 & 0.811 & 0.00117 & 0.397 & -0.00079 & 0.622 \\
\hline EDU & $0.02253^{* * *}$ & 0.000 & -0.00228 & 0.588 & $-0.01078 * * *$ & 0.027 & -0.00651 & 0.230 \\
\hline FAMILY & -0.00904 & 0.284 & 0.01064 & 0.148 & 0.00692 & 0.373 & -0.00600 & 0.514 \\
\hline Social capital & $0.08569 * * *$ & 0.000 & -0.01215 & 0.268 & -0.00182 & 0.871 & -0.01830 & 0.172 \\
\hline TRAINING & -0.03756 & 0.305 & 0.04151 & 0.247 & 0.00542 & 0.878 & 0.04077 & 0.345 \\
\hline CREDIT & $0.11093 * * *$ & 0.002 & -0.01002 & 0.740 & -0.02863 & 0.370 & -0.04646 & 0.235 \\
\hline DISTMARKET & -0.01558 & 0.504 & $-0.03867^{*}$ & 0.088 & -0.02299 & 0.310 & 07019*** & 0.004 \\
\hline WARNING & 0.01877 & 0.639 & $0.09059 * * *$ & 0.001 & 0.02514 & 0.472 & $0.08395 * *$ & 0.052 \\
\hline LIVESTOCK & 0.00421 & 0.317 & 0.00622 & 0.114 & $-0.01575^{* * *}$ & 0.001 & 0.00325 & 0.518 \\
\hline CROP FAILURE & 0.00366 & 0.644 & $0.01695 * * *$ & 0.001 & 0.00165 & 0.814 & -0.00497 & 0.500 \\
\hline CULTIVLAND & 0.02787 & 0.212 & $-0.06595 * * *$ & 0.007 & -0.01297 & 0.602 & $0.05795 * * *$ & 0.027 \\
\hline
\end{tabular}

$* * * * * * *$ Significant at 1,5 , and $10 \%$ probability level, respectively 
as an adaptation method. A unit increase in a number of years of schooling would result in a $22.5 \%$ increase in the probability of small-scale irrigation to adapt to climate change. This might be education that helps farmers to search and use relevant information for their farming practices. On the same vein, education helps farmers to anticipate the consequences of climate change and understand the potential benefit of small-scale irrigation to minimize the possible impact of climate change. This is possible because educated farmers are more likely consulting different agencies that promote climate change adaptation options that would have a significant positive impact to reduce farmers' vulnerability to climate change and variability. This result supports the view of numerous studies that show the positive impact of education on farmers' decision to adopt small-scale irrigation [32, 42, $46,53-55]$.

A study in rural Africa shows that education is an important determining factor to engage in non-farm and skilled employment businesses [80]. It is more crucial that better paid local jobs require formal schooling, usually the completion of secondary school or beyond. Contrary to our expectation, level of education negatively and significantly $(p<0.01)$ determines farmers' decision to adopt livelihood diversification strategies such as offand non-farm activities. A unit increase in a number of years of schooling would result in a $10.8 \%$ decrease in the probability of livelihood diversification strategies to adapt to climate change. This might be due to the fact that educated households may have realized higher earnings from on-farm activity than off-farm and non-farm activities that have low return.

\section{Social capital}

It should be noted that self-help grouping and formation of cooperatives is a more reliable and pragmatic means of achieving social capital and ensuring dissemination and adoption of innovative technology [73, 74]. Membership to many social groups organized at the local level, as a proxy for social capital, is positively and significantly related to the likelihood of adoption small-scale irrigation at $1 \%$ significance level. A unit increase in membership to the social group would result in an $8.6 \%$ increase in the probability of adopting small-scale irrigation to adapt to climate change. The possible explanation of this result is social capital increase awareness and use of climate change adaptation options. It shows a quite promising picture in which social capital is also important resource for the community in evaluating risk and vulnerability imposed by climate variability and change in such a way that it serves both to disseminate information and to shape the way individuals process and understand information to promote small-scale irrigation to combat the negative impact of the change on their farming. Another possible explanation is that social capital helps to understand the usefulness of small-scale irrigation to combat the risk posed by climate change.

The strong social networks can help the communities to have a strong supporting system which can enhance their adaptive capacity to respond to environmental shocks. As group discussants revealed, cooperation in the form of water user group, water shade management group, credit unions, agricultural producer organizations, livestock marketing group, and women credit association have positive effects on the income generating a capacity of their members and this may capacitate farmers' financial status to invest in small-scale irrigation scheme. This result suggests that the role of individual membership to social groups in determining preference can be a useful point to consider since our result indicates that adoption of small-scale irrigation is high for those having a membership to many social groups. Although it is not significant, the sign of membership in organizations on adoption of agronomic practices, livelihood diversification, and SWC is not in the hypothesized direction. This is probably because households are receiving information only limited to irrigation, but information related to different agronomic practices, different ways of creating livelihood options, and techniques of SWC are not circulated effectively by the social groups. The result suggests that while membership in the organization is important to receive information on adaptation strategies, simply membership in the organization is not sufficient for adaptation strategies that need skills. This further suggests a need to supplement by training for capacity development.

Previous studies have shown that social capital, in its different forms, played a crucial role to adopt different adaptation options to reduce environmental shocks that came out from climate variability and change [32, 81, 82]. For instance, Mpogole [82] found that increased membership to social groups would increase the probability of adopting conservation agriculture, drought-tolerant varieties, and irrigation. Similarly, Ortmun and King [81] and Mpogole [82] found that being a member of the social networks and organizations have substantially increased the likelihood to adopt improved and high yielding varieties. On the same vein, Deressa et al. [32] found that social networks increase awareness and use of climate change adaptation options.

\section{Access to credit}

Household access to credit indicates the availability of funds which is positively related to the level of adoption of adaptive strategies [83]. Although access to credit has no significant influence on agronomic practices, 
livelihood diversification, and SWC measures, it has a significant influence on adoption of small-scale irrigation. As expected, the influence of access to credit service on farmer's decision to invest in small-scale irrigation is significantly positive $(p<0.001)$. Having access to credit increases the probability of adoption of small-scale irrigation by $11.1 \%$. This may be explained by the fact that availability of credit minimizes liquidity constrains and thereby enhances adoption of small-scale irrigation. This clearly indicates that those farmers who neither have cash nor access to credit are priced out of using small-scale irrigation. To say it in another way, adopting small-scale irrigation is heavily affected by credit market imperfections. This makes sense because the availability of credit eases the cash constraints and allows farmers to purchase irrigation facilities. This suggests the important role of increased financial institutional support in promoting the use of small-scale irrigation as adaptation option to reduce the negative impact of climate change. Similar results were reported in the previous literature [32, 42, $59,62]$.

\section{Climate warning system}

As hypothesized, better access to early warning about drought and flood before it happened has a significant and positive impact on the likelihood of using agronomic practices and SWC measures on their farmland at 1 and $5 \%$ significance level, respectively. The results reveal that getting access to climate warning about drought and/or flood increases the likelihood of using agronomic practices (9\%), and SWC measures (8.4\%). This implies that farmers who get early warning about drought and/or flood will try to construct SWC measures such as stone bunds, soil bunds, check dams, and hillside terrace either to preserve the moisture content of the soil not to loss of water associated with an increased evapotranspiration due to increased drought or to reduce soil erosion to be happened due to the flood. Moreover, early warning mechanism helps farmers to use drought-tolerant varieties to cope with increased temperature. This result supports the findings of earlier researchers on technology adoption. Phillipo et al. [84] noted that information on climate warning empowered smallholder farmers to adapt to climate variability and change. Alike to this, a study conducted by Deressa et al. [52] in assessing climate change adaptations of smallholder farmers in South Eastern Ethiopia revealed that better access to information on climate change has a significant and positive impact on the likelihood of using different crop varieties. Although it is noted that climate warning system helped increase the uptake of adaptation options, the effective early warning system remains an important concern voiced by survey respondents. This leads to the conclusion that the benefits from adaptation options may be reduced or entirely forgone if the lack of effective early warning system constrains households from adopting adaptation options.

\section{Livestock ownership}

In line with prior expectation, livestock holding in TLU negatively influences household's choice of livelihood diversification strategies at $1 \%$ probability level. This result reveals that a unit increase in a number of livestock in TLU would result in a $15.7 \%$ decrease the probability of creating another source of livelihoods like petty trading and small business as an alternative means of income. This suggests that farmers with lower livestock holding would be obliged to diversify livelihoods into off- and non-farm in order to meet needs. This result is in contrary to the notion that higher livestock ownership would help farmers more likely to have better financial source helping them to create another source of livelihood [85].

\section{Crop loss experience (crop failure)}

Multinomial logit result shows that a number of times a household's crop failed due to the adverse impact of climate change over the last 20 years greatly influenced farmers' decision to adapt to climate change using agronomic practices. The result indicates that a unit increase in the number of times a farmer's crop failed as a result of climate change over the past 20 years could increase the likelihood of adopting agronomic practices by $16.9 \%$ at $p<0.001$ to minimize the adverse effect. This evidence suggests that farmers experience crop loss because climate-related hazards have developed their indigenous knowledge and innovations to respond to the risk. The result is in conformity with the finding of Teshager et al. [86] in their investigation of determinants of adaptation strategies to climate change in the Batti district of Amhara Regional State.

\section{Agroecological setting}

It is noted that different farmers living in different agroecological settings employ different adaptation methods. The results reveal that farming in the Woyina Dega and Dega zone significantly increases the probability of using small-scale irrigation by 14.6 and $19.8 \%$, respectively, as compared with farming in Kolla zone. Similarly, farming in Woyina Dega significantly increases the likelihood of using different livelihood diversification strategies by $10.3 \%$, as compared with Kolla. On the other hand, farming in Woyina Dega and Dega zone significantly reduces the probability of using SWC measures by 27.5 and $31.9 \%$, respectively, compared with farming in Kolla. This suggests that small-scale irrigation and livelihood diversification strategies are widely considered adaptation 
options in both Woyina Dega and Dega agroecology to cope with the risk imposed by climate change and variability. This might be due to high irrigation potential of Weyina Dega and Dega agroecology. Most of the permanent and intermittent rivers which have a potential for small-scale irrigation are found in Woyina Dega and Dega agroecology. More importantly, these rivers are located in a suitable setting for using them for irrigation. Conversely, Kolla agroecology is endowed with a few number of rivers that will be used for irrigation. It is also noted that these rivers are flowing in a gorge which needs huge capital and advanced technology to make use of them for irrigation purpose as compared to rivers found in Woyina Dega and Dega agroecology.

Furthermore, the tendency that the household diversifies livelihoods into agriculture plus off-farm plus nonfarm increases as we go from Kolla to Woyina Dega. This might be due to high infrastructure development in Woyina Dega as compared to Kolla. In a previous study, we have reported differences in access to major infrastructure across the three agroecologies [87]. This study found that households in Kolla agroecology had traveling an average of higher time to the main road, school, veterinary service, market, water point, and health center as compared to Woyina Dega and Dega households. The probable reason is that good infrastructure development increases the incentive of sample farmers to diversify their livelihoods that will help them reduce the negative impact of climate variability and change.

\section{Farm size}

The size of cultivated land is negatively and significantly related to the adoption of agronomic practices in response to climate variability and change in the study area. A unit increase in a hectare of cultivated land would decrease the likelihood of using different agronomic practices by $6.6 \%$. This might be due to the fact that farmers with the large size of cultivated land have less fear to take the risk of climate change than their counterparts. Farmers with the large size of cultivated land have a high probability of having many farm plots with different soil physical and chemical characteristics that have been impacted by climate change differently. It may be this fact that gave farmers confidence not to worry about droughttolerant varieties, crop rotation, and changing planting dates to reduce impact posed by climate change and variability. This result affirms with a study done by Deressa et al. [88] in the Nile basin of Ethiopia to analyze farmers perception and adaptation to climate change, which supports the notion that the negative relationship between farm size and adaptation could be due to the fact that adaptation is plot specific. According to their argument, the need for specific adaptation method in response to climate variability and change is dictated by characteristics of the plot that the size of the farm.

The negative effects of farm size on adopting agronomic practices found here are inconsistent with other studies [59, 77, 84]. For instance, Phillipo et al. [84] support the notion that households with small land holding are more likely to choose traditional crop varieties because of the associated costs to the new crop varieties. They further explained the probable reason for why small land holders do not adopt improved crop varieties; they argued that poor farmers always farm for home consumption; therefore, they are likely to choose varieties that suit them rather than the market.

The model result of this study reveals that size of cultivated land significantly increases the likelihood of using soil conservation measures at $1 \%$ significance level. A unit increase in a hectare of cultivated land would increase the probability of using SWC by $5.6 \%$. The probable reason is that constructing SWC measures will reduce their farm size. As a matter of fact, farmers with large farm size have less risk of reduction to farm size that came out from constructing SWC measures on their farm land. The result is in conformity with the earlier studies $[47,53,57-59]$.

\section{Distance to the main market}

It is noted that adoption of different technologies is thriving in areas with developed rural infrastructure and markets and also where commercial agriculture prevails. As hypothesized, distance from the home of a household to the main market is found to have a significant $(p<0.05)$ negative impact on the likelihood of choosing different agronomic practices. A unit increase in walking hour from the home of a household to the main market would decrease the likelihood of using agronomic practice/ practices by $3.9 \%$. The probable reason is that poor infrastructure development reduces the incentive of farmers to produce surplus production to supply to the markets using different technologies. In addition, distant farmers might have limited access to agricultural extension services; this undermines the potential benefits of using agronomic practices to reduce the high level of production risk imposed by climate variability and change. However, contrary to what one would expect, distance to the main market is found to be positively and significantly affect the rural households' decision to invest in SWC at $1 \%$ level of significance. This may be explained by the fact that households in the remote area have less opportunity cost to adapt labor-intensive adaptation practices (e.g., SWC). The argument by Deressa et al. [32] in favor of our finding, concurs that households in a remote area may be more willing to take up adaptation in order to reduce climate-related risk probably due to the availability of lesser 
income-earning opportunities. This could be further explained distant households from the main market are constrained by the lack of information and lack of access to the market to dispose of their products, have less offfarm employment opportunities, and lead to rely more on traditional strategies. Unlike our result, many kinds of the literature indicated that improving market access for small-scale subsistence farmers would increase their ability to adapt to climate change $[2,30,63,66]$.

\section{Conclusion and policy recommendations}

It has been noted that climate change and variability adversely affect agriculture, which is the major means of livelihoods of smallholder farmers in the study area. As agriculture remains a source of income for rural communities in the study areas, adaptation to climate change and variability is imperative. It is learned that adaptation to this change tends to reduce the negative impact of climate change and variability. Different adaptation options are employed by smallholder farmers in response to climate variability and change in the study area. The main adaptation strategies can be broadly categorized to include small-scale irrigation, agronomic practices, livelihood diversification strategies, and SWC measures. It is learned that adoption of these adaptation options tends to reduce a high production risk imposed by climate variability and change. This indicates that these adaptation options provide a venue to reduce sensitivity and increase the adaptive capacity of smallholder farmers that latter improve their livelihoods and ensure food security.

The study finds that better access to credit allows households to adopt small-scale irrigation. This implies that credit market imperfection can create a barrier for the capital-constrained farm households to participate in small-scale irrigation in the study area. Provision of microcredit facilities complemented with skill development training can help the households to invest in small-scale irrigation to avert the adverse impact of climate change and variability. The study further reveals that household characteristics such as education status of the household heads which could be enhanced through policy intervention have a significant impact on adaptation to climate change using small-scale irrigation. Thus, investment in education systems which increases farmers awareness to invest in small-scale irrigation and that help farmers to specialize on farming in the rural areas can be underlined as a policy option in the reduction of the negative impacts of climate change.

As often stated in climate literature, early warning system increases farmers' preparedness to design and implement adaptation options in response to the expected climate change. This improves adaptive capacity and reduces the sensitivity of smallholder farmers to the negative impact of climate variability and change. In practice, although climate warning system helped increase the adaptive capacity and reduce the sensitivity of smallholder farmers, early warning system remains an important concern voiced by survey respondents. This leads to the conclusion that the benefits from adaptation options may be reduced or entirely forgone if concerns about early warning system constrain households from adopting adaptation options or to limit adoption of adaptation options to few smallholder farmers who have the previously higher adaptive capacity and less sensitive. This implies that additional efforts to increase effective early warning system may have the desired impact on the adoption of SWC measures and agronomic practices as adaptation options.

The results of the study also indicate the important role of social capital in adaptation to climate change. Policy interventions which encourage farmers' membership to many social groups can promote group discussions and better information flows and enhance adaptation to climate change. The result further reveals that farmers living in different agroecological settings used different adaptation options. Thus, the future policy has to aim at providing adaptation technologies through agroecologybased research.

Experience in crop failure is another important variable that affects adoption of agronomic practices positively. With increasing experiences in crop failure, farmers adopt agronomic practices such as using drought-tolerant crop varieties, changing planting dates, and using crop rotation. Thus, future policy to develop and promote drought-tolerant crop varieties can support farmers to better cope with climate change.

\section{Authors' contributions}

Abayineh Amare and Belay Simane generated the idea and designed the study. Abayineh carried out the data collection, data analysis, and write-up. Belay provided statistical assistance and read and revised the manuscript. Both authors read and approved the final manuscript.

\section{Acknowledgements}

We wish to express our profound gratitude to Addis Ababa University; the German Academic Exchange Service (DAAD), Germany; African Climate

Change Fellowship Program; and International Development Research Centre (IDRC) for their financial support in accomplishing this paper. We also want to thank Catharine Roynald for her rigorous comments and suggestions on the manuscript.

\section{Competing interests}

The authors declare that they have no competing interests.

Availability of data and materials

Data sharing is not applicable to this article as no datasets were generated or analyzed during the current study.

Consent for publication

Not applicable. 
Ethics approval and consent to participate

Not applicable.

\section{Funding}

All data collection, data analysis, and write-up of the study were supported by Addis Ababa University, African Climate Change Fellowship Program, and DAAD In-Country Scholarship program.

\section{Appendix}

\section{See Table 6.}

Table 6 Conversion factors used to estimate TLU. Source: Stock et al. [89]

\begin{tabular}{llll}
\hline Animal category & TLU & Animal category & TLU \\
\hline Calf & 0.50 & Donkey (young) & 0.35 \\
Weaned calf & 0.34 & Camel & 1.25 \\
Heifer & 0.75 & Sheep and goat (adult) & 0.13 \\
Cow and oxen & 1.0 & Sheep and goat (young) & 0.06 \\
Horse & 1.10 & Chicken & 0.013 \\
Donkey (adult) & 0.70 & & \\
\hline
\end{tabular}

\section{Publisher's Note}

Springer Nature remains neutral with regard to jurisdictional claims in published maps and institutional affiliations.

Received: 9 October 2017 Accepted: 8 November 2017 Published online: 01 December 2017

\section{References}

1. Bryan E, Deressa TT, Gbetibouo GA, Ringler C. Adaptation to climate change in Ethiopia and South Africa: options and constraints. Environ Sci Policy. 2009;12(4):413-26.

2. Below T, Artner A, Siebert R, Seiber S. Micro-level practices to adapt to climate change for African small-scale farmers: a review of selected literature, vol 953. IFPRI Discuss Paper; 2010, p 28.

3. Glantz M, Gommes R, Ramasamy S. Coping with a changing climate: considerations for adaption mitigation in agriculture (Environment natural resources management series N 15). Fao 2010;120. http://www.lavoisier. $\mathrm{fr} /$ notice/fr9251064450.html.

4. Kahiluoto H, Rimhanen K, Rötter R, Tseganeh B, Kahiluoto H, Rimhanen K, Rötter R, Tseganeh B. Mitigation of climate change to enhance food security: an analytical framework. Forum Dev Stud. 2012;39:51-73.

5. Nhemachena CHR. Micro-level analysis of farmers' adaption to climate change in southern Africa, IFPRI Discussion Paper 00714. Washington: International Food Policy Research Institute (IFPRI); 2007.

6. Ngigi SN. Climate change adaptation strategies: water resources management options for smallholder farming systems in sub-saharan Africa. MDG Cent East South Africa, The Earth Inst Columbia University, New York. 2009;63(1):55. www.astra-project.org.

7. Thornton PK, Jones PG, Alagarswamy G, Andresen JHM. Adapting to climate change: agricultural system and household impacts in East Africa. Agric Syst. 2010;103(2):73-82.

8. Parry ML, Canziani OF, Palutikov JP, van der Linden PJ, Hanson C. Climate change 2007: impacts, adaptation and vulnerability. Contribution of working group II to the fourth assessment report of the intergovernmental panel on climate change. Cambridge: Cambridge University Press; 2007

9. World Bank. Economics of adaptation to climate change, Ethiopia. 2010. https://openknowledge.worldbank.org/handle/10986/12504 License: CC BY 3.0 Unported.
10. Schipper ELCD. Adaptation to climate change in Africa: challenges and opportunities identified from Ethiopia. Glob Environ Change. 2011:21:227-37.

11. Ministry of Finance and Economic Development (MoFED). Estimates of the 2010/11 Base year series (2003 Ethiopian Fiscal year). Addis Ababa; 2013.

12. FAO. The social dimension of adaptation to climate change in Ethiopia. Discussion paper 14. The World Bank, Washington. 2007.

13. Rosenzweig C, Elliott J, Deryng D, Ruane A, Müller C, Arneth A, et al. Assessing agricultural risks of climate change in the 21 st century in a global gridded crop model intercomparison. Proc Natl Acad Sci. 2013;111(9):3268-73.

14. Elizabeth $B$, et al. Adaptation to climate change in Ethiopia and South Africa: options and constraints. Environ Sci Policy. 2009;12(4):413-26.

15. Demeke AB, Keil A, Zeller M. Using panel data to estimate the effect of rainfall shocks on smallholders food security and vulnerability in rural Ethiopia. Clim Chang. 2011;108(1):185-206.

16. Bewket W. Climate change perceptions and adaptive responses of smallholder farmers in central highlands of Ethiopia. J Environ Stud. 2012;69(3):507-23.

17. White L. A climate trend analysis of Ethiopia. US Geol Surv Fact Sheet 2012-3053. 2012:6:1.

18. Ribot J. Vulnerability does not just fall from the sky: toward multi-scale pro-poor climate policy. In: Mearns R, Norton A, editors. Social dimensions of climate change: equity and vulnerability in a warming world. Washington: The World Bank; 2010. p. 47-74.

19. Bardsley D, Wiseman N. Climate change vulnerability and social development for remote indigenous communities of South Australia. Glob Environ Chang. 2012;22:713-23.

20. Mersha E, Boken KV. Agricultural drought in Ethiopia. In: Boken KV, Cracknell AP, Heathcote LR (eds), Monitoring and predicting agricultural drought: a global study. 2005, Oxford University Press, p 227.

21. Cheung W, Senay G, Singh A. Trends and spatial distribution of annual and seasonal rainfall in Ethiopia. Int J Clim. 2008;28(13):1723-34.

22. Conway D, Schipper ELF. Adaptation to climate change in Africa: challenges and opportunities identified from Ethiopia. Glob Environ Change. 2011;21(1):227-37.

23. Gray C, Mueller V. Drought and population mobility in rural Ethiopia. World Dev. 2012;40(1):134-45.

24. Stern N. What is the economics of climate change. World Econ. 2006;7(2):1-10.

25. Kurukulasuriya P, Mendelsohn R. A Ricardian analysis of the impact of climate change on African cropland. Afr J Agric Resour Econ. 2008;2(1):1-23.

26. Reidsma P, Ewert F, Lansink A, Leemans R. Vulnerability and adaptation of European farmers: a multi-level analysis of yield and income responses to climate variability. Reg Environ Change. 2009;9(1):25-40.

27. NMSA. Initial National Communication of Ethiopia to the United Nations Framework Convention on Climate Change (UNFCCC). Addis Ababa; 2001.

28. Kidane G, Abebe T, Degefie T. Estimating crop water use and simulating yield reduction for maize and sorghum in Adama and Miesso districts using the cropwat model. South Africa: Pretoria; 2006.

29. Deressa TT. Measuring the economic impact of climate change on Ethiopian agriculture: Ricardian approach. Washington; 2007. Report No.: 4342.

30. Hassan R, Nhemachena C. Determinants of African farmers' strategies for adapting to climate change: multinomial choice analysis. Afr J Agric Resour Econ. 2008:2(1):83-104.

31. Seo N, Mendelsohn R. Animal husbandry in Africa: climate change impacts and adaptations. Afr J Agric Resour Econ. 2008;2(1):65-82.

32. Deressa TT, Yesuf RMH, Mahmud CRTA. Determinants of farmers' choice of adaptation methods to climate change in the Nile basin of Ethiopia. Glob Environ Chang. 2009;19:248-55.

33. Denekew A, Bekele S. Characterization and Atlas of the Blue Nile Basin and its Sub basins. Addis Ababa: International Water Management Institute; 2009.

34. Hurni $\mathrm{H}$. Agroecological belts of Ethiopia: explanatory notes on three maps at a scale of 1:1000,000. Addis Ababa: Soil conservation research program; 1998

35. Greene W. Econometric analysis. 4th ed. New Jersey: Prentice-hall Inc; 2000 
36. Dorfman J. Modeling multiple adoption decisions in joint framework. Am J Agric Econ. 1996;78:547-57.

37. Chilot Y. The dynamics of soil degradation and incentives for optimal management in Central Highlands of Ethiopia. Pretoria: University of Pretoria; 2007.

38. Chan YH. Basic statistics for doctors, multinomial logistic regression. Singapore Med J. 2005;46(6):259.

39. Komba C, Muchapondwa E. Adaptation to climate change by smallholder farmers in Tanzania. Economic Research Southern Africa (ERSA) Working paper No 299, 2012. http://econra.org/home/index.php?option $=$ comdocman\&task=docdownload\&gid=443\&ltemid=67. Accessed 14 Dec 2016.

40. Brown D, Stephens E, Ouma J, Murithi F, Barrett CB. Livelihood strategies in the rural Kenyan highlands. Afr J Agric Resour Econ 2006;1 (1):21-36.

41. Greene W. Econometric analysis, vol. 4. New York: Macmillan Publishing Company; 2003.

42. Tizale $C$. The dynamics of soil degradation and incentives for optimal management in Central Highlands of Ethiopia. South Africa: University of Pretoria; 2007.

43. Bekele W, Drake L. Soil and water conservation decision behavior of subsistence farmers in the Eastern Highlands of Ethiopia: a case study of the Hunde-Lafto area. Ecol Econ. 2003:46:437-51.

44. Tafa K, Beshah T, Amsalu A, Resource N, Berehan D, Berehan D, et al. Determinants of physical soil and water conservation practices in Ethiopia's Semi-Arid tropics: the case of Bati District. Soc Basic Sci Res Rev. 2009;2(12):525-41.

45. Dolisca F, Carter R, McDaniel J, Shannon D, Jolly C. Factors influencing farmers' participation in forestry management programs: a case study from Haiti. For Ecol Manag. 2006;236:324-31.

46. Anley Y, Bogale A, Haile-Gabriel A. Adoption decision and use intensity of soil and water conservation measures by smallholder subsistence farmers in Dedo district, Western Ethiopia. Land Degrad Dev. 2007;18:289-302.

47. Amsalu A, De Graaff J. Determinants of adoption and continued use of stone terraces for soil and water conservation in an Ethiopian highland watershed. Ecol Econ. 2007;61:294-302.

48. Arega B, Woldeamlak B, Melanie N. Rural households' livelihood assets, strategies and outcomes in drought-prone areas of the Amhara Region, Ethiopia: case study in Lay Gaint District. Afr J Agric Res. 2013;8(46):5716-27.

49. Gebreyesus B. Determinants of livelihood diversification: the case of Kembata Tambaro Zone, Southern Ethiopia. J Poverty Invest Dev. 2016;23:1-10

50. Bayard B, Jolly C, Shannon D. The economics of adoption and management of alley cropping in Haiti. J Environ Manag. 2007;84:62-70.

51. Asfaw A, Admassie A. The role of education on the adoption of chemica fertilizer under different socioeconomic environments in Ethiopia. Agric Econ. 2004;30(3):215-28.

52. Deressa TT, Yehualashet $H$, Rajan DS. Climate change adaptations of smallholder farmers in South Eastern Ethiopia. J Agric Ext Rural Dev. 2014;6(11):354-66.

53. Asrat P, Kassa B, Hamito D. Determinants of farmers' willing to pay for soil conservation practices in the southern highlands of Ethiopia. Land Degrad Dev. 2004;15:423-38.

54. Sidibe A. Farm-level adoption of soil and water conservation techniques in Northern Burkina Faso. Agric Water Manag. 2004:71(3):211-24.

55. Damena D. Determinants of farmers'land management practices: the case of Tole District, South West Shewa Zone, Oromia National Regional State, Ethiopia. J Sustain Dev Afr. 2012;14(1):76-96.

56. Maddison D. The perception of and adaptation to climate change in Africa. Pretoria, South Africa; 2006. Report No.: 10.

57. Tadesse M, Belay K. Factors influencing the adoption of soil conservation in Southern Ethiopia the case of Gunnuno. Agric Rural Dev Trop Sub Trop. 2004;105(1):40-62.

58. Kassa Y, Beyene F, Haji J, Legesse B. Impact of integrated soil and water conservation program on crop production and income in West Harerghe Zone, Ethiopia. Int J Environ Monit Anal. 2013;1 (4):111-20.

59. Gbetibouo G. Understanding farmers' perceptions and adaptations to climate change and variability: the case of the Limpopo Basin, South Africa. Washington: International Food Policy Research Institute (IFPRI); 2009.

60. Nyangena W. Social determinants of soil and water conservation in rural Kenya. Environ Dev Sustain. 2008;10(6):745-67.
61. Gebreyesus B. Determinants of livelihood diversification: the case of Kembata Tambaro Zone, Southern Ethiopia. J Poverty Invest Dev. 2016;23:1-10.

62. Kandlinkar M, Risbey J. Agricultural impacts of climate change: if adaptation is the answer, What is the question? Clim Change. 2000;45:529-39.

63. Deressa T, Hassan RM, Ringler C. Perception of and adaptation to climate change by farmers in the Nile basin of Ethiopia. Agric Sci. 2011;149:23-31.

64. Below T, Mutabazi K, Kirschke D, Franke C, Sieber S, Siebert R, et al. Can farmers' adaptation to climate change be explained by socio-economic household-level variables? Glob Environ Chang. 2012;22:223-35.

65. Lapar M, Pandely S. Adoption of soil conservation: the case of Philippine uplands. Agric Econ. 1999;21:241-56.

66. Piya L, Maharjan KL, Joshi NP, Lall K. Determinants of adaptation practices to climate change by Chepang households in the rural Mid-Hills of Nepal. Reg Environ Chang. 2013;13(2):437-47.

67. Lemma T. Diversity in livelihoods and farmers strategies in Hararghe highlands, Eastern Ethiopia. South Africa: University of Pretoria; 2003.

68. Eshete B. Livelihood strategies of smallholder farmers and income poverty in draught prone areas: the case of Gena- Bosa woreda, SNNPRS. Dire Dawa: Haramaya University; 2007.

69. Thornton PK, Jones PG, Owiyo TM, Kruska RL, Herrero M, Kristjanson P, et al. Mapping climate vulnerability and poverty in Africa. Kenya: Nairobi; 2006.

70. IPCC. Climate change 2007: synthesis report. Contribution of working Group I, II and III to the fourth assessment report of the Intergovernmental panel on climate change. In: IPCC. London; 2007.

71. Aker JC. Dial "A" for agriculture: a review of information and communication technologies for agricultural extension in developing countries. Agric Econ. 2011;42(6):631-47.

72. Nhemachena C, Hassan R. Micro-level analysis of farmers'adaptation to climate change in Southern Africa. Washington: International Food Policy Research Institute (IFPRI); 2007.

73. Coleman J. Social capital and the creation of human capital. Am J Sociol. 1998;94:95-120.

74. Dikito M. Social capital: empowering women to achieve food Security. Washington: International Food Policy Research Institute (IFPRI); 2001

\section{(Report No.: 9)}

75. Legesse B, Ayele Y, Bewket W. Smallholder farmers' perceptions and adaptation to climate variability and climate change in Doba district, west Hararghe, Ethiopia. Asian J Empir Res. 2013;3(3):251-65.

76. Tessema Y, Aweke C, Endris G. Understanding the process of adaptation to climate change by small-holder farmers: the case of east Hararghe Zone, Ethiopia. Agric Food Econ. 2013;1 (1):13.

77. Bryan E, Deressa T, Gbetibouo G, Ringler C. Adaptation to climate change in Ethiopia and South Africa: options and constraints. Environ Sci Policy. 2009;12(4):413-26.

78. CSA (Central Statistical Agency). The federal democratic republic of Ethiopia statistical abstract for 2003. Federal Democratic Republic of Ethiopia, Addis Ababa; 2007.

79. Swinton SM. More social capital, less erosion: Evidence from Peruvian Altiplano. Tampa; Paper presented at the annual meeting of the American Agricultural Economics Association from July 30-August 02, 2000.

80. Barrett C, Reardon T, Webb P. Nonfarm income diversification and household livelihood strategies in rural Africa: concepts, dynamics, and policy implications'. Food Policy. 2001;26(4):315-31.

81. Ortmun GF, King RP. Agricultural cooperatives II: Can they facilitate access to small-scale farmers in South Africa to input and product market? Agrekon. 2007;46(2):219-44.

82. Mpogole H. Round potatoes production in southern highlands of Tanzania: Market preferences, farmers varieties selection and profitability. 2013.

83. Yirga C, Hassan R. Social costs and incentives for optimal control of soil nutrient depletion in the central highlands of Ethiopia. Agric Syst. 2010;103(3):153-60

84. Phillipo F, Bushesha M, Mvena ZSK. Adaptation strategies to climate variability and change and its limitations to smallholder farmers. A literature search. Agric Rural 2015;5(3):77-87. http://ageconsearch.umn.edu/ bitstream/209973/2/2-553-5(3)2015-AJARD-77-87.pdf.

85. Tazeze A, Haji J, Ketema M. Climate change strategies of smallholder farmers: the case of Babile district, East Harerghe Zone of Oromia Regional state of Ethiopia. J Econ Sustain Dev. 2012;3:1-12. 
86. Teshager M, Adgo E, Tilahun T. Investigating the determinants of adaptation strategies to climate change: a case of Batti District, Amhara Regio. Int J Agric Res. 2014;9(4):169-86.

87. Amare A, Simane B. Climate change induced vulnerability of smallholder farmers in the Blue-Nile Basin. Addis Ababa: Ethiopia; 2016.

88. Deressa T, Hassan R, Ringler C. Perception of and adaptation to climate change by farmers in the Nile basin of Ethiopia. J Agric Sci. 2010;50(1):1-9.
89. Stock H, Bezabih E, Berhanu A, Borowiceki A, Shimelis W. Farming system and farm management practices of smallholders in Harerghe highlands. In: Farming system and resource economics in the Tropics, vol 11. Kiel: Wissenschaftsverlag Vauk; 1991

\section{Submit your next manuscript to BioMed Central and we will help you at every step:}

- We accept pre-submission inquiries

- Our selector tool helps you to find the most relevant journal

- We provide round the clock customer support

- Convenient online submission

- Thorough peer review

- Inclusion in PubMed and all major indexing services

- Maximum visibility for your research

Submit your manuscript at

www.biomedcentral com/submit 